\title{
Tingkat Pengetahuan Tentang "DAGUSIBU"Obat Antibiotik Pada Masyarakat Desa Sungai Awan Kiri Kecamatan Muara Pawan Kabupaten Ketapang Tahun 2017
}

\section{The "DAGUSIBU" Knowledge About Antibiotic Drugs In Society Sungai Awan Kiri Village Muarapawan Districts Ketapang Regency In 2017}

\author{
Heny Puspasari ${ }^{*}$, Siti Harida, Dwi Fitriyani \\ Akademi Farmasi Yarsi Pontianak \\ Jl. Panglima A'im Pontianak
}

Submitted : 30-07-2018

Reviewed : 24-08- 2018

Accepted : 28-08-2018

\begin{abstract}
ABSTRAK
Penggunaan antibiotik yang relatif tinggi menimbulkan masalah dan merupakan ancaman bagi munculnya peningkatan dan penyebaran resistensi antibiotik. Ada beberapa faktor yang mempengaruhi penggunaan antibiotik pada mayarakat. Salah satu faktor yang mempengaruhi yaitu seperti tingkat pendidikan, pengetahuan dari masyarakat dan penjelasan oleh dokter. Tujuan penelitian ini adalah untuk mengetahui tingkat pengetahuan tentang DAGUSIBU obat antibiotik pada masyarakat Desa Sungai Awan Kiri Kecamatan Muara Pawan Kabupaten Ketapang. Penelitian ini merupakan jenis penelitian survei deskriptif dengan menggunakan kuesioner. Sampel dalam penelitian ini adalah 100 orang Masyarakat Desa Sungai Awan Kiri Kecamatan Muara Pawan Kabupaten Ketapang. Hasil penelitian menunjukkan bahwa tingkat pengetahuan Masyarakat Desa Sungai Awan Kiri Kecamatan Muara Pawan Kabupaten Ketapang sudah sangat baik dengan persentase $25 \%$, pada kategori baik $60 \%$ dan pada kategori cukup baik $15 \%$.
\end{abstract}

Kata kunci : Pengetahuan, DAGUSIBU, Obat Antibiotik dan Masyarakat Desa

\begin{abstract}
The used of relatively high antibiotic poses a problem and threat rise and spread of antibiotic resistance. There are several factors that affect the use of antibiotics in community. One of the influencing factors such as the level of education, knowledge of the community dan doctors explanation. The purpose of this research is to determine the level of knowledge of DAGUSIBU antibiotik drugs in the community Desa Sungai Awan Kiri Kecamatan Muara Pawan Kabupaten Ketapang. This research is a descriptive survey that using qustioner. Sample of the research is 100 people Desa Sungai Awan Kiri Kecamatan Muara Pawan Kabupaten Ketapang . The result showed that the level knowledge the community in very good category with percentage of $25 \%$, good category $60 \%$ and quite enough 15).
\end{abstract}

Keywords: Knowledge, DAGUSIBU, antibiotic drugs and society. 


\section{Penulis korespondensi:}

Heny Puspasari

Akademi Farmasi Yarsi Pontianak

Jl. Panglima A'im Pontianak

Email: heny24puspasari@gmail.com

\section{PENDAHULUAN}

Berbagai penyakit infeksi menjadi pembunuh terbesar di dunia anak- anak dan dewasa muda. Infeksi mencapai lebih dari 13 juta kematian pertahun dinegara berkembang. Tingkat pengetahuan merupakan salah satu faktor yang sangat berpengaruh dalam upaya peningkatan derajat kesehatan masyarakat.

Antibiotik merupakan obat yang banyak diresepkan pada pasien, namun penggunaannya sering kali tidak tepat, akibatnya terjadilah peningkatan resistensi kuman terhadap antibiotik, resistensi terjadi ketika bakteri berubah dalam satu atau lain hal yang menyebabkan turun atau hilangnya efektifitas obat, senyawa kimia atau bahan lainya yang digunakan untuk mencegah atau mengobati infeksi. Hal ini menjadi salah satunya faktor kurangnya informasi yang akurat dan tingkat pendidikan masyarakat yang masih sangat rendah sehingga dapat mengakibatkan tingginya tingkat konsumsi yang tidak tepat (Baltazar., 2009).

Penggunan antibiotik akan menguntungkan dan memberikan efek bila diresepkan dan dikonsumsi sesuai dengan aturan, namun sekarang ini antibiotik telah digunakan secara bebas dan luas oleh masyarakat tanpa mengetahui dampak dari pemakaian tanpa aturan, penggunaan tanpa aturan mengakibatkan keefektifan dari antibiotik akan berkurang (Yarta et $a l, 2015)$.

Pembelian antibiotik tanpa resep dokter di apotek (7\%). Amoksisilin merupakan antibiotik paling banyak dibeli secara swamedikasi sebesar (77\%) ampisilin, tetrasiklin, fradiomisingramisidin, dan ciprofloksasin. Antibiotik tersebut rata-rata dibeli untuk mengobati gejala flu, demam, batuk, sakit tenggorokan, sakit kepala dan gejala sakit ringan lainnya dengan lama penggunaan sebagai besar kurang dari lima hari (Widayati et al, 2011).

Salah satu cara pengolahan obat yang baik dan benar adalah DAGUSIBU, cara ini menjelaskan tatacara pengolahan obat dari awal mereka dapatkan hingga saat obat sudah tidak dikonsumsi lagi dan akhirnya dibuang.

Pengetahuan adalah suatu proses mengingat dan mengenal kembali objek yang telah dipelajari melalui panca indra pada suatu bidang tertentu secara baik. Pengetahuan dalam penggunaan obat DAGUSIBU merupakan hal yang terpenting karena pengetahuan merupakan salah satu cara agar dapat menggunakan obat, menyimpan, mendapatkan, dan membuang obat sesuai dengan konsep DAGUSIBU. Kategori pengetahuan meliputi kemampuan untuk mengatakan kembali dari ingatan hal-hal khusus dan umum, metode dan proses atau mengingat suatu pola, susunan, gejala atau peristiwa.

Desa Sungai Awan kiri merupakan Desa yang terletak didaerah Kecamatan Muara pawan Kabupaten Ketapang Provinsi Kalimantan Barat, penggunaan antibiotik oleh masyarakat didaerah Desa Sungai Awan Kiri ini cukup tinggi. Dampak tersebut harus ditanggulangi secara efektif sehingga perlu diperhatikan prinsip penggunaan antibiotik harus sesuai indikasi penyakit, dosis, cara pemberian, interpal waktu, lama pemberian, keefektifan, mutu, keamanan, dan harga.

Data yang diperoleh dari UPTD Puskesmas Desa Sungai Awan Kiri Kecamatan Muara Pawan Kabupaten Ketapang Tahun 2016 menyebutkan bahwa yang termasuk dalam 10 besar penyakit paling banyak diderita oleh masyarakat yang berkunjung ke UPTD Puskesmas Desa Sungai Awan Kiri Kecamatan Muara Pawan Kabupaten Ketapang adalah penyakit Dispepsia 4.175 orang, ISPA 2.914 orang, Dermatitis kontak alergi 1.338 orang, Hipertensi Esensial 9.846 orang, dan Batuk 823 orang. Penyakit ini tentunya diperlukan 
antibiotik sebagai pengobatan. Antibiotik adalah obat yang digunakan untuk mengobati penyakit akibat terjadi infeksi pada saluran pencernaan dan penyakit lainya.

Berdasarkan data yang telah didapat dari UPTD Puskesmas Sungai Awan Kiri belum pernah dilakukan penelitian mengenai Tingkat Pengetahuan Tentang DAGUSIBU Obat Antibiotik pada Masyarakat Desa Sungai Awan Kiri Kecamatan Muara Pawan Kabupaten Ketapang, maka peneliti tertarik untuk melakukan penelitian mengenai tingkat pengetahuan tentang DAGUSIBU obat antibiotik pada masyarakat Desa Sungai Awan Kiri Kecamatan Muara Pawan Kabupaten Ketapang tahun 2017.

\section{METODE PENELITIAN}

Penelitian ini merupakan jenis penelitian survei deskriptif dengan menggunakan kuesioner. Penelitian ini dilakukan di Desa Sungai Awan Kiri Kecamatan Muara Pawan Kabupaten Ketapang. Subjek pada penlitian ini adalah 100 orang Masyarakat Desa Sungai Awan Kiri Kecamatan Muara Pawan Kabupaten Ketapang, yaitu (usia 18-66 tahun, berakal sehat, bersedia menjadi responden dan bisa membaca dan menulis).

Pengambilan data dilakukan dengan wawancara mengunakan kuesioner yang telah divalidasi sembelumnya. Data diolah di analisis bertujuan untuk mendeskripsikan karakteristik variabel penelitian. Pengetahuan diukur dari tiga kelompok didistribusikan pengetahuannya berdasarkan karakteristik responden yakni jenis kelamin, umur, pendidikan terakhir, pekerjaan dan RT/RW. Analisi ini mengahasilkan distribusi Frekuensi dan persentase dari tiap variabel (Notoadmodjo, 2010).

\section{HASIL DAN PEMBAHASAN}

Desa Sungai Awan Kiri merupakan desa yang terletak di daerah Kecamatan Muara Pawan Kabupaten Ketapang Provinsi Kalimantan Barat, dengan jumlah penduduk 3.030 jiwa. Penggunaan antibiotik oleh masyarakat di daerah Desa Sungai Awan Kiri ini cukup tinggi. Dampak tersebut harus ditanggulangi secara efektif sehingga perlu diperhatikan prinsip penggunaan antibiotik harus sesuai indikasi penyakit, dosis, cara pemberian, interfal waktu, lama pemberian ke efektifan, mutu, keamanan, dan harga.

Data yang diperoleh dari UPTD Puskesmas Desa Sungai Awan Kiri Kecamatan Muara Pawan Kabupaten Ketapang Tahun 2016 menyebutkan bahwa yang termasuk dalam 10 besar penyakit paling banyak diderita oleh masyarakat yang berkunjung ke UPTD Puskesmas Desa Sungai Awan Kiri Kecamatan Muara Pawan Kabupaten Ketapang.

Karakteristik Responden berdasarkan jenis kelamin di Desa Sungai Awan Kiri Kecamatan Muara Pawan Kabupaten Ketapang dapat dilihat pada tabel di bawah ini :

Tabel I. Distribusi Frekuensi Jenis Kelamin Responden Desa Sungai Awan Kiri Kecamatan Muara Pawan Kabupaten Ketapang Tahun 2017.

\begin{tabular}{cccc}
\hline No & Jenis Kelamin & Jumlah & Persentase (\%) \\
\hline 1 & Laki-laki & 47 & 47 \\
2 & Perempuan & 53 & 53 \\
& Total & $\mathbf{1 0 0}$ & $\mathbf{1 0 0}$ \\
\hline
\end{tabular}

(sumber: Data Skunder, 2017).

Berdasarkan tabel diatas, menunjukkan bahwa dari 100 responden di Desa Sungai Awan Kiri Kecamatan Muara Pawan Kabupaten Ketapang Provinsi Kalimantan Barat, untuk jenis kelamin laki-laki dengan persentase sebanyak 47 responden (47\%) dan jenis kelamin perempuan yaitu sebanyak 53 responden (53\%). Hal ini sesuai dengan penelitian lain mengatakan bahwa jenis kelamin perempuan yang lebih banyak dikarenakan Perbedaan antara pengetahuan antara laki-laki dan perempuan kemungkinan disebabkan oleh pedulinya perempuan terhadap kesehatan yang mencangkup obat-obatan, selain itu sumber informasi yang didapat perempuan kemungkinan lebih banyak karena fakta bahwa perempuan sering berinteraksi dan lebih aktif dari laki-laki dalam dunia sosial masyarakat seperti kegiatan PKK,dll. (Rusli Rolan, Febriana Lizma, Prima Desten) 
Tabel II. Karakteristik Responden Berdasarkan Kelompok Umur Responden Desa Sungai Awan Kiri Kecamatan Muara Pawan Kabupaten Ketapang Tahun 2017.

\begin{tabular}{ccc}
\hline Kelompok Umur & Jumlah & Persentase \\
\hline $18-24$ Tahun & 19 & 19 \\
$25-31$ Tahun & 15 & 15 \\
$32-38$ Tahun & 22 & 22 \\
$39-45$ Tahun & 11 & 11 \\
$46-52$ Tahun & 23 & 23 \\
$53-59$ Tahun & 7 & 7 \\
$60-66$ Tahun & 3 & 3 \\
Total & $\mathbf{1 0 0}$ & $\mathbf{1 0 0 \%}$ \\
\hline
\end{tabular}

(sumber : Data Skunder, 2017).

Berdasarkan tabel diatas, menunjukan jumlah responden paling banyak adalah 46-52 tahun dengan persentase sebanyak 23 responden (23\%) dan paling sedikit yang berumur 60 66 tahun sebanyak 3 responden (3\%). Hal ini sama dengan penelitian lain mengatakan bahwa umur merupakan salah satu faktor yang mungkin mempengaruhi tingkat pengetahuan seseorang menegenai antibiotik. (Moeda Geryana, Carolina Wijaya, Yuliani Nyoman Ni).

Tabel III. Karakteristik Responden Berdasarkan Jenis Pekerjaan Pada Responden Desa Sungai Awan Kiri Kecamatan Muara Pawan Kabupaten Ketapang Tahun 2017.

\begin{tabular}{cccc}
\hline No & Jenis Pekerjaan & Jumlah & Persentase (\%) \\
\hline 1 & SWASTA & 40 & 40 \\
2 & PNS/TNI/POLRI & 23 & 23 \\
3 & IBU RUMAH TANGGA & 28 & 28 \\
4 & DLL & 9 & 9 \\
& Total & $\mathbf{1 0 0}$ & $\mathbf{1 0 0 \%}$ \\
\hline
\end{tabular}

Berdasarkan tabel diatas, responden paling banyak yang memiliki pekerjaan sebagai Swasta sebanyak 40 responden (40\%),dan yang paling sedikit memiliki pekerjaan yang lainnya sebanyak 9 responden $9 \%$. Hal ini sama denga penelitian lain mengatakan bahwa pekerjaan mempengaruhi tingkat pengetahuan masyarakat mengenai antibiotik (Moeda Geryana, Carolina Wijaya, Yuliani Nyoman Ni).

Tabel IV. Distribusi Tingkat Pengetahuan Responden Desa Sungai Awan Kiri Kecamatan Muara Pawan Kabupaten Ketapang Tahun 2017.

\begin{tabular}{cccc}
\hline Pengetahuan & $\begin{array}{c}\text { Persentase } \\
\text { Responden }\end{array}$ & $\begin{array}{c}\text { Jumlah } \\
\text { Responden }\end{array}$ & Persentase (\%) \\
\hline Pengetahuan Sangat Baik & $81 \%-100 \%$ & 25 & 25 \\
Pengetahuan Baik & $61 \%-80 \%$ & 60 & 60 \\
Pengetahuan Cukup Baik & $41 \%-60 \%$ & 15 & 15 \\
Pengetahuan Kurang Baik & $21 \%-40 \%$ & 0 & 0 \\
Pengetahuan Sangat Kurang Baik & $0 \%-20 \%$ & 0 & 0 \\
Jumlah & $\mathbf{1 0 0 \%}$ & $\mathbf{1 0 0}$ & $\mathbf{1 0 0 \%}$ \\
\hline
\end{tabular}

Berdasarkan tabel diatas, responden dengan tingkat pengetahuan paling banyak yaitu sangat baik sebanyak 60 responden (60\%), tingkat pengetahuan baik sebanyak 25 responden $(25 \%)$, dan pengetahuan cukup baik sebanyak 15 responden $(15 \%)$. 
Tabel V. Persentase Responden Tentang Mendapatkan DAGUSIBU Obat Antibiotik pada Masyarakat Desa Sungai Awan Kiri Kecamatan Muara Pawan Kabupaten Ketapang Tahun 2017.

\begin{tabular}{|c|c|c|c|c|c|c|c|c|c|c|c|}
\hline \multirow[b]{2}{*}{ No } & \multirow[b]{2}{*}{ DAGUSIBU } & \multicolumn{10}{|c|}{ Jumlah } \\
\hline & & $\begin{array}{l}\text { Sangat } \\
\text { Baik } \\
(81 \%- \\
100 \%)\end{array}$ & $\%$ & $\begin{array}{l}\text { Baik } \\
(61 \%- \\
80 \%)\end{array}$ & $\%$ & $\begin{array}{l}\text { Cukup } \\
\text { Baik } \\
(41 \%- \\
60 \%)\end{array}$ & $\%$ & $\begin{array}{l}\text { Kurang } \\
(21 \%- \\
40 \%)\end{array}$ & $\%$ & $\begin{array}{l}\text { Sangat } \\
(0 \%- \\
20 \%)\end{array}$ & $\%$ \\
\hline 1 & Dapat & 60 & 60 & 0 & 0 & 38 & 38 & 0 & 0 & 2 & 2 \\
\hline 2 & Guna & 87 & 87 & 0 & 0 & 0 & 0 & 0 & 0 & 13 & 13 \\
\hline 3 & Simpan & 50 & 50 & 0 & 0 & 0 & 0 & 0 & 0 & 50 & 50 \\
\hline 4 & Buang & 16 & 16 & 51 & 51 & 32 & 32 & 0 & 0 & 1 & 1 \\
\hline
\end{tabular}

Pengetahuan seseorang merupakan hal yang mempengaruhi tindakan seseorang. Pengetahuan dapat menjadi salah satu faktor yang dapat mempengaruhi penggunaan antibiotik secara tidak rasional dengan pedoman terapi, akan meningkatkan berkembangnya resistensi bakteri terhadap antibiotik. Proses pengumpulan data dimulai dengan melakukan penelusuran kerumah rumah masyarakat Desa Sungai Awan Kiri Kecamatan Muara Pawan Kabupaten Ketapang. Data yang diambil dari masyarakat Desa Sungai Awan Kiri meliputi pekerjaan, umur, pendidikan terakhir, jenis kelamin, dan RT/RW.

Berdasarkan hasil penelitian tingkat pengetahuan Masyarakat Desa Sungai Awan Kiri terhadap penggunaan DAGUSIBU obat antibiotik dapat dihasilkan dengan dengan kategori Sangat Baik sebanyak 25 responden (25\%), pengetahuan Baik sebanyak 60 responden (60\%), pengetahuan Cukup Baik sebanyak 15 responden (15\%). Dilihat dari hasil tersebut menunjukkan bahwa masyarakat Desa Sungai Awan Kiri Kecamatan Muara Pawan memiliki pengetahuan Baik. Dengan demikian dapat dikatakan bahwa responden yang memiliki pengetahuan baik lebih banyak dari pada responden yang memiliki pengetahuan sangat baik. Hal ini sama dengan penelitian lain dengan judul penelitian Tingkat Pengetahuan dan Sikap Mahasiswa Universiti Sains Malaysia Kampus Kejuruteraan, Ibong Tebal, Pulau Pinang tentang Penggunaan Antibiotik menyatakan bahwa sebanyak 57\% mempunyai sikap baik (Hardiana, 2011).

Pengetahuan responden sangat berpengaruh terhadap penggunaan antibiotik. Penelitian yang dilakukan oleh Irma Fatmawati tentang tinjaun pengetahuan, sikap dan perilaku penggunaan antibiotik pada mahasiswa kesehatan dan non kesehatan di Universitas Muhammadiyah, Surakarta menunjukkan adanya hubungan pengetahuan dan sikap atau perilaku penggunaan antibiotik. Ada beberapa faktor yang mungkin dapat mempengaruhi kurangnya tingkat pengetahuan Masyarakar tersebut. Salah satu faktornya seperti tingkat pendidikan dari masyarakat, penjelasan oleh dokter, informasi dari media lain yang dapat menimbulkan adanya kesalahan saat mengkonsumsi antibiotik.

Cara yang dapat digunakan untuk meningkatkan pengetahuan penggunaan antibiotik dikalangan Masyarakat Desa Sungai Awan Kiri yaitu dapat dilakukan penyuluhan tentang penggunaan antibiotik.

\section{KESIMPULAN}

Tingkat pengetahuan tentang DAGUSIBU obat Antibiotik pada masyarakat desa Sungai Awan Kiri Kecamatan Muara Pawan Kabupaten Ketapang Tahun 2017 berada dalam kategori sangat baik sebanyak 25\% responden, sedangkan pada kategori baik sebanyak $60 \%$ responden dan pada kategori cukup baik sebanyak 15\% responden. Jadi Tingkat 
Pengetahuan DAGUSIBU Obat Antibiotik Pada Masyarakat Desa Sungai Awan Kiri

Kecamatan Muara Pawan Kabupaten Ketapang Tahun 2017 dapat disimpulkan sudah baik.

\section{DAFTAR PUSTAKA}

Ardhany, SD., Anugrah, RO., \& Harum Y. 2016. Tingkat Pengetahuan Masyarakat Desa Basawang Kecamatan Teluk Sampit Tentang Penggunaan Antibiotik Sebagai Pengobatan Infeksi. a. Prosiding Rakernas dan pertemuan Ilmiah Tahunan Ikatan Apoteker Indonesia 2016. Universitas Muhammadiyah Palangkaraya (2541-0474).

Andarwati, R. 2014. Gambaran Pengetahuan Dan Sikap Ibu Rumah Tangga Terhadap Penggunaan Antibiotik Di Desa Kuta Mbelin Kecamatan Lau Baleng Kabupaten karo.

Baltazar, F., Azevedo, M.M., Pinheiro, C., Yaphe, J. 2009. Portuguese students' knowledge of antibiotics: a cross-sectional study of secondary school and university students in Braga, 3 (359), 1-6, BMC Public Health, Portugal.

Depkes RI. 2009. Profil Kesehatan Indonesia.Jakarta: Departemen Republik indonesia.(Online)(http://depkes.go.id/Profil_Kesehatan_Indonesia.pdf, diakses (24 November 2017)

Fernandez, Maria, Anna, Beatrik. 2013. Studi Penggunaan Antibiotik Tanpa Resep Di Kabupaten Manggarai dan Manggarai Barat - NTT.

Hardiana. 2011. Tingkat Pengetahuan dan Sikap Mahasiswa Universitas Sains Malaysia Kampus Kejuruteraan, Ibong Tebal, Pulau Pinang TentangPenggunaan Antibiotik Pada Tahun 2011.

Kemenkes RI. 2011. Pedoman Umum Penggunaan Antibitotik. Jakarta: Kementrian Kesehatan Republik Indonesia.(Online) (http;//Kemenkes.go.id/Pedoman Umum Penggunaan Antibiotik.pdf,diakses 30 november 2017).

Notoatmodjo, S. 2003. Pendidikan \& perilaku Kesehatan. PT. Rineka Cipta, 127.

Notoatmodjo, S.2010. Metodologi Penelitian Kesehatan. Rineka Cipta: Jakarta.

Pandean, F., Tjitrosanto, H., Goenawi, LR. 2013. Profil Pengetahuan Masyarakat Kota Manado Mengenai Antibiotik Amoksisilin. Pharmacon Jurnal Ilmiah FarmasiUNSRAT. Program Studi Farmasi FMIPA UNSRAT Manado, 95115.

Rusli, Rolan., Febrina, Lizma., Prima, Desten. 2015. Profil Pengetahuan Antibiotik Amoksisilin Masyarakat Desa Batu-Batu, Kutai Kartanegara. Prosiding Seminar Nasional Kefarmasian Ke-1 2015. Fakultas Farmasi Universitas Mulawarma, Samarinda, Kalimantan Timur.

Setiabudy, R. 2007. Pengantar Antimikroba, Dalam : Ganiswara, S.G., dkk (Eds). Famakologi dan terapi, Edisi 5, Jakarta : Bagian Farmakologi FKUI.

Veronica, NW .1988. Obat-obatan: Penerbit KANISIUS

World Health Organiz Sation. 2004. WHO Medicines Strategy Countries At The Core 20042007. Geneva: World Health Organization.

Widayati, A., Suryawati, S., Crespigny, C., Hiller, J., E. 2012. Knowledge and beliefs about antibiotics amog people in Yogyakarta CityIndonesia: a cross sectional populationbased survey, Antimicrob Resist Infect Control 1 (1): 38, BMC.

Yarza H.L., Yanwirasti, LI. 2015. Hubungan Tingkat Pengetahuan Dan Sikap Dengan Penggunaan Antibiotik Tanpa Resep Dokter, Jurnal Kesehatan Andalas 2015: 4 (1) 
Yuliani, NN., Wijaya, W., Moeda, G. 2014. Tingkat Pengetahuan Masyarakat RW.IV Kelurahan Fotein Kota Kupang Terhadap Penggunaan Antibiotik. Jurnal Info kesehatan. Volume12. 
